Supplement of Atmos. Chem. Phys. Discuss., 15, 2355-2404, 2015

http://www.atmos-chem-phys-discuss.net/15/2355/2015/

doi:10.5194/acpd-15-2355-2015-supplement

(C) Author(s) 2015. CC Attribution 3.0 License.

(c) (i)

\title{
Assessment of crop yield losses in Punjab and Haryana using two years of
} continuous in-situ ozone measurements

B. Sinha et al.

Correspondence to: B. Sinha (bsinha@iisermohali.ac.in) 
In our study we use a high quality dataset of in-situ ozone measurements at a regionally representative suburban site called Mohali to assess ozone related crop yield losses for wheat, rice, cotton and maize for Punjab and the neighbouring state Haryana for the years 2011-2013.

Crop yield loss estimates are calculated using two different exposure metrics, AOT40 and M7

5 and are inter-compared for the two major crop growing seasons of Kharif (June-October) and Rabi (November-April).

For Rabi season crop yield losses are calculated for wheat and maize and for Kharif season crop yield losses are calculated rice, maize and cotton.

In supplementary text $\mathrm{S} 1$ we discuss the growth stages during which these crops are potentially

10 sensitive to ozone related yield losses, as well as the time periods during which the plants reach those growth stages in the northern Indo Gangetic plain.

Supplementary tables S2 to S5 show the ozone exposure for rice, wheat, maize and cotton sowed on different sowing dates in the cropping season according to different exposure metrics and relative yields calculated according to different exposure-yield relationships.

\section{Supplementary text S1}

\subsection{Rice}

The life cycle of the rice plant is generally 100 to 210 days. The developmental phases are broadly classified into vegetative phase (from seed germination to panicle initiation), reproductive phase (from panicle initiation to anthesis) and the ripening phase (from anthesis to full maturity) (Vergara, 1991). However, for quantifying ozone damage the early vegetative phase from seed germination to emergence can be neglected, as plants are not affected by air pollution prior to emergence. In Asia, emergence typically takes two weeks after sowing. After sowing, anthesis is reached 70-100 days and maturity in 100-140 days respectively (Timsina and Humphreys, 2006). Typically crops are not harvested directly after reaching maturity (the stage at which the flag leaves and spikes start turning yellow). In the absence of drying facilities, farmers wait till grains reach the optimum moisture content for threshing. During the corresponding drying period (typically up to 2 weeks) no further ozone damage can be incurred. While direct seeding of rice both into wet and dry soil is possible (Vergara, 1991), sowing seeds into nurseries and transplanting them into the puddled fields is still the most popular rice planting method in Punjab and Haryana. In Punjab, May 15th to May 30th is recommended as the optimum time of sowing for all the recommended rice varieties (agripb.gov.in, 2014). Seedlings are transplanted 25-45 days after sowing. The greening of most rice growing areas in Punjab takes place between June 1st and July 1st (Upadhyay et al., 2008) and would correspond to the date at which rice is transplanted into the fields. However, the ozone sensitive growth stage would already be reached two weeks prior to transplantation. Paddy crop typically reaches maturity in September or early in October. According to remote sensing estimates harvesting starts in the first half of September in a limited area and is completed by October 11th in most of the state (Upadhyay et al., 2008). Only in a few regions harvest takes place after October 11th (Upadhyay et al., 2008). For calculating the economic losses in Punjab and Haryana due to ozone three time periods have been considered:

40 Period 1: May 16th (emergence) to September 15th (maturity)

Period 2: June 1st (emergence) to September 30th (maturity)

Period 3: June 16th (emergence) to October 15th (maturity)

Several studies report crop yields for a wider range of transplantation dates (Chahal et al., 2007; Jalota et al., 2009; Mahajan et al., 2009; Brar et al., 2012). Since the variance of the average AOT40 and M7 indices of the same months in different years is much smaller that the difference of the average AOT40 and M7 for different reference periods outlined above, those datasets in combination with our measurements can be used to investigate potential yield reductions due to ozone. Since some studies reported yields for a larger variety of transplantation dates, we also consider the following 
additional time windows while deriving the empirical relationship between crop yields and ozone exposure:

Period 4: April 15th (emergence) to August 15th (maturity)

Period 5: May 1st (emergence) to September 1st (maturity)

\subsection{Wheat}

The plant development of wheat is generally classified into the following stages: germination to emergence (beneath the ground, not sensitive to $\mathrm{O}_{3}$ ); growth stages 1-3, wherein growth stage 3, which includes the grain filling period (from anthesis to maturity) is most susceptible to $\mathrm{O}_{3}$ damage (Picchi et al., 2010). Physiological maturity is usually defined as the time when the flag leaf and spikes turn yellow. Harvesting can occur any time after physiological maturity but typically does not occur till two weeks after, because of high kernel moisture (Porter and Gawith, 1999). In Punjab and Haryana wheat is sown in October (middle) to December (beginning). Emergence takes two weeks. In Asian winter wheat varieties anthesis is typically reached 80-100 days after sowing and maturity 110- 140 days after sowing (Timsina and Humphreys, 2006). Sowings in October are considered early, sowings in the first two weeks of November timely and sowing after that are considered to be late (Coventry et al., 2011). Generally late sowings reach maturity faster - after 4 rather than 5 months - as they are exposed to higher temperatures and ozone in the later part of their development during the grain filling state (Porter and Gawith, 1999; Timsina and Humphreys, 2006). The sowing time depends heavily on the harvesting time of the previously planted Kharif crop (Chahal et al., 2007; Buttar et al., 2013) and on the tillage method adopted. Conventional field preparation takes at least two weeks for clearing the crop residue ploughing and disking. Planting an additional potato crop in between Kharif and Rabi also delays the wheat sowing. A large number of studies report crop yields for different tillage methods and sowing dates (Chahal et al., 2007; Jalota et al., 2008; Coventry et al., 2011; Buttar et al., 2013; Ram et al., 2013). In this study we consider the following time windows for the ozone sensitive period from emergence (two weeks after sowing) till maturity (4-5 months after sowing).

Period 1: November 1st (emergence) to 15th March (maturity)

Period 2: November 16th (emergence) to 31st March (maturity)

Period 3: December 1st (emergence) to 15th April (maturity)

Period 4: December 16th (emergence) to 15th April (maturity)

Period 5: January 1st (emergence) to 30th April (maturity)

80 Period 2 and Period 3 are most relevant for calculating ozone related losses in the rice-wheat cropping system and correspond to the most popular sowing dates in the rice-wheat cropping system as reported by satellite retrievals (Lobell et al., 2013). However, since crop yields corresponding to the other sowing dates are reported in the literature we use the available data to estimate doseresponse relationships for Asian winter wheat cultivars.

\subsection{Maize}

The plant development of maize is generally classified into the vegetative stage, tasseling stage, cob formation stage and milk stage. The vegetative stage is completed 30-40 days post emergence and tasselling, cob formation and milk stage 60-70,70-80 and 80-90 days post emergence, respectively (Cakir, 2004). Emergence can take as little as 5-7 days in warm soil and up to 30 days under cold conditions. In Punjab and Haryana kharif maize is sown in June or July and harvested in September or October (Upadhyay et al., 2008; Ghuman and Sur , 2001). Spring maize is grown from December or January - April. Maize has extremely high crop yields in spring, but cultivation of spring maize is actively discouraged due to high water consumption. Nevertheless, cultivation of spring maize does occur in Jalandhar, Hoshiarpur, Gurdaspur and parts of Malwa. We investigate two periods to evaluate potential yield losses of maize due to ozone for each of the growing seasons.

Kharif:

Period 1: 15th June (emergence) to 15th September (maturity) 
Period 2: 1st July (emergence) to 1st October (maturity)

Rabi:

\subsection{Cotton}

The growth stages of cotton are commonly divided into emergence, presquare, preflower, midseason, and late season growth (Oosterhuis , 1990). Cotton is a 240 day crop in Punjab. The recommended sowing date is April (beginning) to 15 May (agripb.gov.in, 2014; Jalota et al., 2008). Early sowing helps to escape the attack of American bollworm to great extent but also exposes the crop to high ozone concentrations during summer. Whenever sowing has to be delayed due to delayed harvesting of the rabi crops or unavailability of canal water, the cultivated area decreases as some farmers opt to plant other kharif crops instead, however, on a limited area sowing can occur as late as May end. Emergence of cotton takes 5-10 days. The period in which cotton is sensitive to ozone damage hence begins approximately one to two weeks after sowing. Cotton sown in April is typically ready for the first picking in the third week of September to beginning of October (Oosterhuis , 1990; Buttar et al., 2013); the second picking takes place in November and the third picking in December. A fourth picking is also possible, if the rabi crop is sown into the standing cotton (Buttar et al., 2013) or if the field is left barren during rabi season. In Punjab and Haryana picking is performed manually. The practise of defoliation, prior to one single machine picking, which is widely followed in the West is not followed in India as a consequence the plant continues to be sensitive to $\mathrm{O}_{3}$ damage throughout the picking period. Picking continues into December or even January and the termination of the picking often conflicts with the ideal sowing dates of the following rabi crop. In the cotton-wheat rotation wheat is often sown far later than the ideal recommended date. To cover the entire range of potential ozone damage, three time windows are investigated:

Period 1: 1st May - 15th December; three pickings

Period 2: 31st May - 15th December; three pickings

Period 3: 1st May - 31st December; four pickings

125 It should be noted, however, that these time windows do not correspond to the same number of pickings. 
Table 1. Ozone exposure according to different exposure indices and relative yields for rice. Data for the five periods used to plot Figure 3 is provided in the table. Period (P) 1-3 correspond to the periods in which rice is usually grown in Punjab and Haryana and the average yield loss of these three periods is used to calculate crop production loss and economic loss for each fiscal year.

\begin{tabular}{lcccccccc}
\hline Time & AOT40 & W126 & M7 & M12 & $\begin{array}{c}\mathrm{RY}_{A O T 40} \\
\text { Mills et al. } \\
(2007)\end{array}$ & $\begin{array}{c}\mathrm{RY}_{M 7} \\
\text { Adams et al. } \\
(1989)\end{array}$ & $\begin{array}{c}\text { RY } \\
\text { Indian } \\
\text { OTC } \\
\text { studies }\end{array}$ & $\begin{array}{c}\mathrm{RY}_{M 7} \\
\text { Indian } \\
\text { OTC } \\
\text { studies }\end{array}$ \\
\hline 2012 P1 & 25641 & 37.27 & 55 & 51 & 0.84 & 0.97 & 0.75 & 0.69 \\
2012 P2 & 19788 & 27.13 & 51 & 47 & 0.86 & 0.97 & 0.80 & 0.75 \\
2012 P3 & 16715 & 21.82 & 49 & 44 & 0.87 & 0.98 & 0.82 & 0.78 \\
2012 P4 & 35640 & 52.29 & 64 & 60 & 0.80 & 0.95 & 0.65 & 0.59 \\
2012 P5 & 31853 & 47.47 & 60 & 56 & 0.82 & 0.96 & 0.70 & 0.63 \\
\hline Average P1-3 & 20715 & 28.74 & 52 & 47 & 0.86 & 0.97 & 0.79 & 0.74 \\
\hline 2013 P1 & 20839 & 27.37 & 53 & 49 & 0.86 & 0.97 & 0.78 & 0.74 \\
2013 P2 & 15330 & 18.25 & 49 & 45 & 0.88 & 0.98 & 0.82 & 0.80 \\
2013 P3 & 12623 & 13.98 & 47 & 42 & 0.89 & 0.98 & 0.84 & 0.82 \\
2013 P4 & 29259 & 41.27 & 60 & 55 & 0.83 & 0.96 & 0.70 & 0.66 \\
2013 P5 & 25498 & 35.63 & 56 & 52 & 0.84 & 0.96 & 0.74 & 0.70 \\
\hline Average P1-3 & 16264 & 19.87 & 49 & 45 & 0.88 & 0.98 & 0.81 & 0.79 \\
\hline
\end{tabular}

\section{Supplementary table $\mathbf{S 2}$}


Table 2. Ozone exposure according to different exposure indices and relative yields for wheat. Data for the five periods used to plot Figure 5 is provided in the table. Period 2 (P2) and Period 3 (P3) correspond to the periods in which wheat is usually grown in Punjab and Haryana in the rice-wheat cropping cycle, while Period 4 (P4) and 5 (P5) correspond to the cotton-wheat cropping cycle. The average yield loss of the rice-wheat cycle is used to calculate crop production loss and economic loss for each fiscal year as most of the area is cultivated in the rice-wheat cropping system.

\begin{tabular}{lccccccccc}
\hline Time & AOT40 & W126 & M7 & M12 & $\begin{array}{c}\mathrm{RY}_{A O T 40} \\
\text { Mills } \\
\text { et al. } \\
(2007)\end{array}$ & $\begin{array}{c}\mathrm{RY}_{M 7} \\
\text { Lesser } \\
\text { et al. } \\
(1990)\end{array}$ & $\begin{array}{c}\mathrm{RY}_{M 7} \\
\text { Heck } \\
\text { et al. } \\
(1984 b)\end{array}$ & $\begin{array}{c}\mathrm{RY}_{A O T 40} \\
\text { Indian } \\
\text { OTC } \\
\text { studies }\end{array}$ & $\begin{array}{c}\mathrm{RY}_{M 7} \\
\text { Indian } \\
\text { OTC } \\
\text { studies }\end{array}$ \\
\hline 2012 P1 & 15843 & 17.99 & 49 & 41 & 0.73 & 0.93 & 0.85 & 0.74 & 0.60 \\
2012 P2 & 15807 & 17.33 & 49 & 41 & 0.74 & 0.93 & 0.86 & 0.75 & 0.60 \\
2012 P3 & 16168 & 17.40 & 49 & 42 & 0.73 & 0.93 & 0.86 & 0.75 & 0.59 \\
2012 P4 & 14754 & 15.95 & 49 & 43 & 0.75 & 0.93 & 0.85 & 0.74 & 0.63 \\
2012 P5 & 17110 & 19.33 & 52 & 46 & 0.71 & 0.92 & 0.84 & 0.69 & 0.57 \\
\hline Average P2-3 & 15987 & 17.36 & 49 & 42 & 0.73 & 0.93 & 0.86 & 0.75 & 0.59 \\
\hline 2013 Period-1 & 11384 & 12.69 & 42 & 36 & 0.81 & 0.96 & 0.91 & 0.88 & 0.71 \\
2013 Period-2 & 9887 & 9.71 & 40 & 35 & 0.83 & 0.96 & 0.92 & 0.90 & 0.75 \\
2013 Period-3 & 11375 & 11.34 & 41 & 37 & 0.81 & 0.96 & 0.91 & 0.88 & 0.71 \\
2013 Period-4 & 10012 & 9.73 & 41 & 37 & 0.83 & 0.96 & 0.91 & 0.89 & 0.75 \\
2013 Period-5 & 13817 & 15.25 & 46 & 41 & 0.77 & 0.94 & 0.88 & 0.81 & 0.65 \\
\hline Average P2-3 & 10631 & 10.53 & 41 & 36 & 0.82 & 0.96 & 0.91 & 0.89 & 0.73 \\
\hline
\end{tabular}

\section{Supplementary table S3}


Table 3. Ozone exposure according to different exposure indices and relative yields for cotton. Period 1 (P1) and Period 2 (P2) correspond to the periods in which cotton is usually grown.

\begin{tabular}{lcccccc}
\hline Time & AOT40 & W126 & M7 & M12 & $\begin{array}{c}\text { RY } \\
\text { Mills } \\
\text { Mill } \\
\text { et al. } \\
(2007)\end{array}$ & $\begin{array}{c}\mathrm{RY}_{M 7} \\
\text { Heck } \\
\text { et al. } \\
(1984 b)\end{array}$ \\
\hline 2012 P1 & 47926 & 68.33 & 57 & 51 & 0.30 & 0.91 \\
2012 P2 & 33728 & 45.91 & 53 & 47 & 0.53 & 0.91 \\
2012 P3 & 48342 & 68.70 & 56 & 50 & 0.30 & 0.92 \\
\hline Average & 40825 & 57.12 & 55 & 49 & 0.42 & 0.91 \\
P1-2 & & & & & & \\
\hline 2013 P1 & 40029 & 52.65 & 55 & 48 & 0.43 & 0.92 \\
2013 P2 & 27312 & 33.12 & 51 & 45 & 0.63 & 0.92 \\
2013 P3 & 41046 & 55.56 & 53 & 51 & 0.41 & 0.93 \\
\hline Average & 33670 & 42.89 & 53 & 47 & 0.53 & 0.92 \\
P1-2 & & & & & & \\
\hline
\end{tabular}

\section{Supplementary table S4}


Table 4. Ozone exposure according to different exposure indices and relative yields for rabi and kharif maize.

\begin{tabular}{lcccccc}
\hline Time & AOT40 & W126 & M7 & M12 & $\begin{array}{c}\text { RY }_{A O T 40} \\
\text { Mills } \\
\text { et al. } \\
(2007)\end{array}$ & $\begin{array}{c}\mathrm{RY}_{M 7} \\
\text { Heck } \\
\text { et al. } \\
(1984 b)\end{array}$ \\
\hline 2012 P1 & 11346 & 14.79 & 46 & 43 & 0.90 & 0.99 \\
2012 P2 & 7522 & 8.39 & 43 & 39 & 0.91 & 0.99 \\
\hline Average & 9434 & 11.59 & 45 & 41 & 0.91 & 0.99 \\
\hline 2011/2012 P3 & 9824 & 10.00 & 48 & 42 & 0.90 & 0.99 \\
2011/2012 P4 & 15406 & 17.91 & 56 & 50 & 0.88 & 0.98 \\
\hline Average & 12615 & 13.96 & 52 & 46 & 0.89 & 0.99 \\
\hline 2013 P1 & 9496 & 10.80 & 46 & 42 & 0.90 & 0.99 \\
2013 P2 & 7209 & 7.15 & 44 & 40 & 0.91 & 0.99 \\
\hline Average & 8353 & 8.98 & 45 & 41 & 0.91 & 0.99 \\
\hline 2012/2013 P3 & 6219 & 5.54 & 40 & 36 & 0.92 & 0.99 \\
2012/2013 P4 & 12455 & 14.13 & 51 & 46 & 0.89 & 0.99 \\
\hline Average & 9337 & 9.84 & 46 & 41 & 0.91 & 0.99 \\
\hline
\end{tabular}

\section{Supplementary table S5}




\section{References}

agripb.gov.in. http://agripb.gov.in/pub/pdf/cotton_brief.pdf and http://agripb.gov.in/pub/pdf/agronomic_ practices_of_rice.pdf. Retrieved on 06.06.2014.

Brar S.K., Mahal S.S., Brar A.S., Vashist K.K., Sharma N., Buttar G.S.: Transplanting time and seedling age affect water productivity, rice yield and quality in north-west India, Agricultural Water Management, 115 , 217-222, doi: ,2012.

Buttar G.S., Sidhu H.S., Singh V., Jats M.L, Gupta R., Singh Y. and Singh B.: Relay planting of wheat in cotton: An innovative technology for enhancing productivity and profitability of wheat in cotton-wheat production systems of South Asia, Experimental Agriculture, 49, 19-30, doi: ,2013.

Cakir R.: Effect of water stress at different development stages on vegetative and reproductive growth of corn, Field Crops Research, 89, 1-16, doi: ,2004.

Chahal G.B.S., Sood A., Jalota S.K., Choudhury B.U. and Sharma P.K.: Yield, evapotranspiration and water productivity of rice (Oryza sativa L.) and wheat (Triticum aestivum L.) system in Punjab (India) as influenced by transplanting date of rice and weather parameters, Agricultural water management, 88, 14-22, doi: ,2007.

Coventry D.R., Gupta R.K., Yadav A., Poswal R.S., Chhokar R.S., Sharma R.K., Yadav V.K., Gill S.C., Kumar A., Metha A., Kleeman S.G.L., Bonamanof A. and Cummin J.A.: Wheat quality and productivity as affected by varieties and sowing time in Haryana, India, Field Crops Research, 123, 214-225, doi: ,2011.

Ghuman B.S. and Sur H.S.: Tillage and residue management effects on soil properties and yields of rainfed maize and wheat in a subhumid subtropical climate, Soil and Tillage Research, 58, 1-10, doi: ,2001.

Jalota S.K., Buttar G.S., Sood A., Chahal G.B.S., Ray S.S. and Panigrahy S.: Effects of sowing date, tillage and residue management on productivity of cotton (Gossypium hirsutum L.), Soil and Tillage Research, 99, 76-83, doi: ,2008.

Jalota S.K., Singh K.B., Chahal G.B.S, Gupta R.K., Chakraborty S., Sood A., Ray S.S. and Panigrahy S.: Integrated effect of transplanting date, cultivar and irrigation on yield, water saving and water productivity of rice (Oryza sativa L.) in Indian Punjab: Field and simulation study, Agricultural Water Management, 96, 1096-1104, doi: ,2009.

Lobell D.B., Ortiz-Monasterio I., Sibley A.M. and Sohu V.S.: Satellite detection of earlier wheat sowing in India and implications for yield trends, Agricultural Systems ,115, 137-143,2013.

Mahajan G., Bharaj T.S. and Timsina J.: Yield and water productivity of rice as affected by time of transplanting in Punjab, India, Agricultural Water Managment, 96, 525-532,2009.

Oosterhuis D.M.: Growth and development of a cotton plant. In: Nitrogen Nutrition of Cotton: Practical Issues. American Society of Agronomy, Madison, WI, 1-24.,1990.

Panigrahy S., Upadhyay G., Ray S.S. and Parihar J.S.: Mapping of Cropping System for the Indo-Gangetic Plain Using Multi-Date SPOT NDVI-VGT Data, Journal of the Indian Society Remote Sensing, 38, 627-632,2010.

Picchi V., Iritia M., Quaroni S., Saracchic M., Viola P. and Faoro F.: Climate variations and phenological stages modulate ozone damages in field-grown wheat. A three-year study with eight modern cultivars in Po Valley (Northern Italy), Agriculture, Ecosystems and Environment ,135, 310-317,2010.

Porter J.R. and Gawith M.: Temperatures and the growth and development of wheat: a review, Agriculture, European Journal of Agronomy, 10, 23-36,1999.

170 Ram H., Dadhwal V., Vashist K.K. and Kaur H.: Grain yield and water use efficiency of wheat (Triticum aestivum L.) in relation to irrigation levels and rice straw mulching in North West India, Agricultural Water Management, 128, 92-101,2013.

Timsina J. and Humphreys E.: Performance of CERES-Rice and CERES-Wheat models in rice?wheat systems: A review, Agricultural Systems, 90, 5-531,2006.

175 Upadhyay G., Ray S.S. and Panigrahy S.: Derivation of Crop Phenological Parameters using Multi-Date SPOTVGT-NDVI Data: A Case Study for Punjab, J. Indian Soc. Remote Sens., 36, 37-50,2008.

Vergara B.S.: Rice Plant Growth and Development. In: Luh BS (ed.) Rice 13. Springer, New York, 13-22, 1991. 